\title{
Ketamine for the treatment of acute pain
}

\author{
William K. Silverstein MD, David N. Juurlink MD PhD, Jonathan S. Zipursky MD
}

Cite as: CMAJ 2021 November 1;193:E1663. doi: 10.1503/cmaj.210878

\section{Ketamine's analgesic and anesthetic effects are dose dependent}

Ketamine is a phencyclidine (PCP) derivative that exerts its effects primarily through $\mathrm{N}$-methyl-D-aspartate receptor inhibition. ${ }^{1}$ At low doses $(0.1-0.3 \mathrm{mg} / \mathrm{kg})$, ketamine produces mainly analgesia. Dissociative anesthesia and psychomimetic effects occur with higher doses $(\geq 1.0 \mathrm{mg} / \mathrm{kg}$ ).

2

\section{Ketamine is an effective analgesic at subanesthetic doses}

Low-dose ketamine is an effective analgesic in several settings. ${ }^{2}$ Intravenous ketamine at subanesthetic doses reduces postoperative pain scores and increases time to patients' first analgesic request. ${ }^{3}$ For acute pain, low-dose ketamine has analgesic effects comparable to morphine, with similar need for rescue analgesia. ${ }^{4}$ Ketamine can be administered parenterally as an intermittent (over 10-15 min) or continuous infusion. Clinicians should start at a low dose $(0.1 \mathrm{mg} / \mathrm{kg}$ every 4 hours for intermittent; $0.1 \mathrm{mg} / \mathrm{kg} / \mathrm{h}$ for continuous infusion) and increase if needed, to a maximum dose of $0.35 \mathrm{mg} / \mathrm{kg}$ (intermittent) or $0.25 \mathrm{mg} / \mathrm{kg} / \mathrm{h}$ (continuous). ${ }^{2}$

\section{3}

\section{Low-dose ketamine is safe}

The adverse effects associated with higher-dose ketamine (nausea, vomiting, vivid dreams, hallucinations, dissociation) do not occur more commonly at doses used to treat pain than with placebo. ${ }^{2,3}$ Studies comparing low-dose ketamine versus morphine for the treatment of acute pain show no differences in the incidence of adverse events. ${ }^{4}$

\section{Clinicians should assess for contraindications before starting treatment}

Ketamine is not recommended in patients with psychosis, severe cardiovascular disease or liver dysfunction. ${ }^{2}$ Given limited data on safety in pregnancy, clinicians should seek expert opinion if considering use in this setting.

\section{Use of ketamine for the treatment of acute pain can have opioid-sparing effects}

When added to opioids for acute pain management, ketamine reduces pain scores and total opioid dose without increasing sedation or other adverse effects. ${ }^{2}$ The respiratory depression associated with opioids is also avoided. Benefits may extend beyond the hospital stay, since reduced opioid consumption after discharge in patients treated perioperatively with intravenous ketamine has been reported. ${ }^{5}$

\section{References}

1. Hirota K, Lambert DG. Ketamine: New uses for an old drug? $\mathrm{Br} \mathrm{J}$ Anaesth 2011;107:123-6.

2. Schwenk ES, Viscusi ER, Buvanendran A, et al. Consensus guidelines on the use of intravenous ketamine infusions for acute pain management from the American Society of Regional Anesthesia and Pain Medicine, the American Academy of Pain Medicine, and the American Society of Anesthesiologists. Reg Anesth Pain Med 2018;43:456-66.

3. Brinck E, Tiippana E, Heesen M, et al. Perioperative intravenous ketamine for acute postoperative pain in adults. Cochrane Database Syst Rev 2018;(12):CD012033.

4. Balzer N, McLeod SL, Walsh C, et al. Low-dose ketamine for acute pain control in the emergency department: a systematic review and meta-analysis. Acad Emerg Med 2021;28:444-54.

5. Loftus RW, Yeager MP, Clark JA, et al. Intraoperative ketamine reduces perioperative opiate consumption in opiate-dependent patients with chronic back pain undergoing back surgery. Anesthesiology 2010;113:639-46

Competing interests: Jonathan Zipursky reports receiving payments from private law firms for medicolegal opinions regarding the safety and effectiveness of drugs, outside the submitted work. No other competing interests were declared.

This article has been peer reviewed.

Affiliations: Department of Medicine (Silverstein, Juurlink Zipursky), University of Toronto; Division of Clinical Pharmacology and Toxicology (Juurlink, Zipursky), Sunnybrook Health Sciences Centre; Institute of Health Policy, Management, and Evaluation (Juurlink, Zipursky), University of Toronto; ICES Central (Juurlink), Toronto, Ont.

Content licence: This is an Open Access article distributed in accordance with the terms of the Creative Commons Attribution (CC BY-NC-ND 4.0) licence, which permits use, distribution and reproduction in any medium, provided that the original publication is properly cited, the use is noncommercial (i.e., research or educational use), and no modifications or adaptations are made. See: https://creativecommons.org/licenses/by-nc-nd/4.0/

Correspondence to: William Silverstein, William.Silverstein@mail.utoronto.ca

CMAJ invites submissions to "Five things to know about ..." Submit manuscripts online at http://mc. manuscriptcentral.com/cmaj 